\title{
Marine Star-Shaped-Aggregate-Forming Bacteria: Agrobacterium atlanticum sp. nov.; Agrobacterium meteori sp. nov.; Agrobacterium ferrugineum sp. nov., nom. rev.; Agrobacterium gelatinovorum sp. nov., nom. rev.; and Agrobacterium stellulatum sp. nov., nom. rev. $\dagger$
}

\author{
HANS-JÜRGEN RÜGER ${ }^{1 *}$ AND MANFRED G. HÖFLE ${ }^{2} \ddagger$
}

Alfred-Wegener-Institut für Polar- und Meeresforschung, D-2850 Bremerhaven, ${ }^{1}$ and Max-Planck-Institut für Limnologie, Abteilung Mikrobenökologie, D-2320 Plön, ${ }^{2}$ Germany

\begin{abstract}
Two new species of aerobic, gram-negative, peritrichously flagellated or nonmotile marine bacteria usually forming star-shaped aggregates were isolated from northeastern Atlantic Ocean bottom sediments. These organisms resembled eight star-shaped-aggregate-forming bacterial species from the Baltic Sea originally ascribed to the genus Agrobacterium but not included on the Approved Lists of Bacterial Names because of their questionable relationships to true agrobacteria. These two sets of star-shaped-aggregate-forming bacteria were compared by means of phenotypic data, DNA base compositions, DNA-DNA relatedness, and one-dimensional electrophoretic analysis of low-molecular-weight RNAs (5S rRNA and tRNA). According to the results of genotyping, the northeastern Atlantic Ocean isolates and three of the Baltic Sea species formed a group of closely related bacteria that could not be excluded from the genus Agrobacterium with certainty. Until more genotypic data are available, these five marine species are regarded as a distinct subdivision of the genus Agrobacterium consisting of Agrobacterium atlanticum sp. nov. (type strain, $1480^{\mathrm{T}}=\mathrm{DSM} 5823^{\mathrm{T}}$ ), $A$. meteori $^{\mathrm{m}}$ sp. nov. (type strain, $1_{1513^{\mathrm{T}}}=\mathrm{DSM} 5824^{\mathrm{T}}$ ), A. ferrugineum sp. nov. nom. rev. emend. (type strain, ATCC $25652^{\mathrm{T}}$ ), A. gelatinovorum sp. nov. nom. rev. emend. (type strain, ATCC $25655^{\mathrm{T}}$ ), and $A$. stellulatum sp. nov. nom. rev. emend. (type strain, ATCC $15215^{\mathrm{T}}$ ). "A. aggregatum", proved to be a later subjective synonym of A. stellulatum, which had priority. The remaining four Baltic Sea species, "A. agile," "A. kieliense," "A. luteum," and "A. sanguineum," could not be placed in the new subdivision of Agrobacterium.
\end{abstract}

The formation of star-shaped aggregates is a phenomenon frequently occurring in bacteria, especially in members of the family Rhizobiaceae (22). Jennings (21), presenting some photomicrographs in 1898, was the first to observe starshaped-aggregate formation in bacteria. In 1954, Stapp and Knösel (41) studied star-shaped-aggregate formation processes in some Agrobacterium and Rhizobium strains, and Knösel (25) reported star-shaped clusters in a culture of Phyllobacterium rubiacearum. A marine star-shaped-aggregate-forming bacterium described by Siebert and Schwartz in 1956 (37) was regarded by Stapp and Knösel (41) as a new species, Agrobacterium stellulatum. Additional marine- or brackish-water-type bacteria with star-shaped-aggregateforming abilities were isolated by Ahrens (1) and Ahrens and Rheinheimer (2) from the Baltic Sea. These organisms resembled $A$. stellulatum and were therefore described as new Agrobacterium species, namely, A. aggregatum, A. agile, A. ferrugineum, A. gelatinovorum, A. kieliense, A. luteum, and $A$. sanguineum. In a personal communication with O. N. Allen, Ahrens later withdrew this proposal (3). Consequently, the species names of the Baltic Sea isolates, as well as of $A$. stellulatum, were not included on the Approved Lists of Bacterial Names (38) and subsequent validation lists and therefore have no standing in bacterial nomenclature.

\footnotetext{
* Corresponding author.

† Contribution no. 398 of the Alfred-Wegener-Institute for Polar and Marine Research.

¥ Present address: Gesellschaft für Biotechnologische Forschung mbH., Abt. Mikrobiologie, D-3300 Braunschweig, Germany.
}

From sediments of the northwestern African upwelling area, Rüger (31) isolated 74 strains of marine, mostly starshaped-aggregate-forming bacteria that could be regarded as belonging to two new species of the same taxon as $A$. stellulatum and the marine Agrobacterium species described by Ahrens (1) and Ahrens and Rheinheimer (2). From DNA-rRNA hybridization experiments, De Smedt and De Ley (9) concluded that these species are not members of the genus Agrobacterium, and Kersters and De Ley (23) stated that these strains belong to one of the four rRNA superfamilies established by De Ley (7) which contains the genera Agrobacterium, Rhizobium, Acetobacter, Gluconobacter, Spirillum, and several other genera which are considered members of subclass alpha of the new class Proteobacteria proposed by Stackebrandt et al. (40).

Our phenotypic and genotypic data do not definitely support the exclusion of most of the marine strains from genus Agrobacterium. As a pro tempore measure, therefore, we propose a distinct subdivision of the genus Agrobacterium to accommodate those marine star-shaped-aggregateforming bacteria which were originally placed in the genus Agrobacterium as A. aggregatum, A. ferrugineum, A. gelatinovorum, and $A$. stellulatum and the star-shaped-aggregateforming isolates from the northwestern African upwelling area, which are described here as the new species $A$. atlanticum and $A$. meteori. Our studies revealed that the species name $A$. aggregatum is a later subjective synonym of $A$. stellulatum, which has priority. The Baltic Sea isolates "Agrobacterium agile," "A. kieliense," "A. luteum," and 
TABLE 1. Selected strains from 55 A. atlanticum and 19 A. meteori isolates and culture collection strains used for substrate utilization tests and genotypic studies

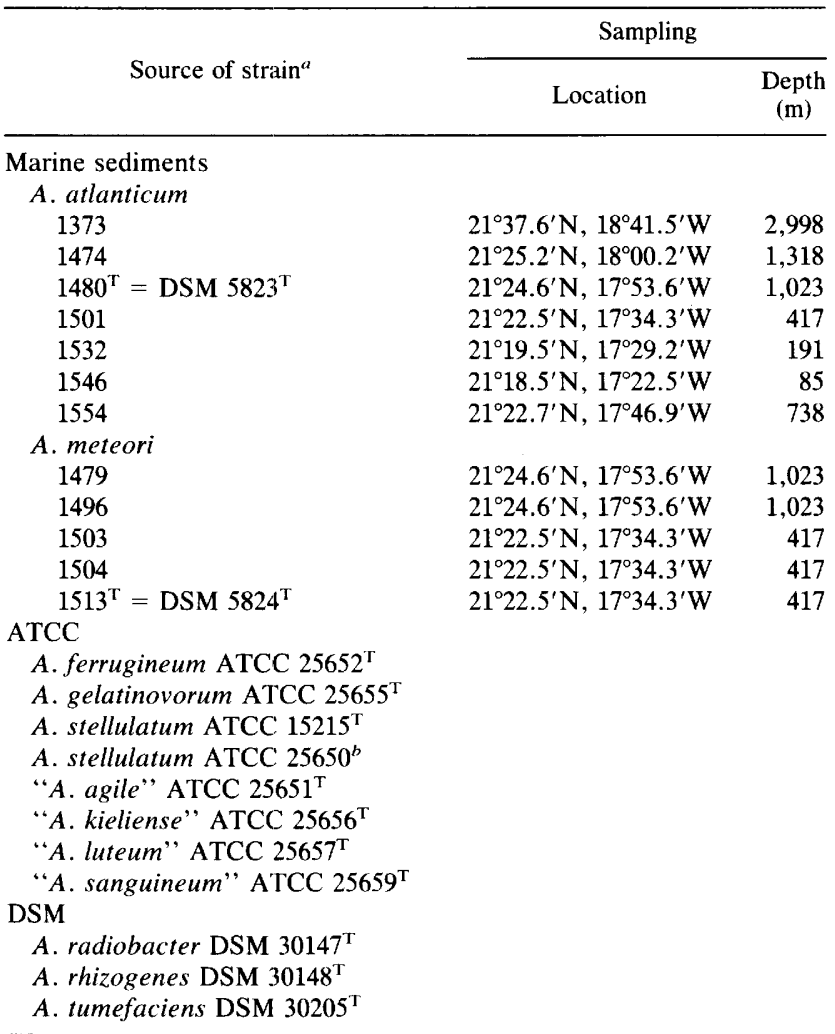

a ATCC, American Type Culture Collection; DSM, Deutsche Sammlung von Mikroorganismen und Zellkulturen.

${ }^{b}$ Received as $A$. aggregatum.

"A. sanguineum" could not be assigned to the new subdivision of genus Agrobacterium.

\section{MATERIALS AND METHODS}

Bacterial strains. During the 36 th cruise of the German research vessel Meteor in 1975, sediment bacteria were isolated at near-shore stations and from up to a depth of about 3,000 $\mathrm{m}$ in the northwestern African upwelling region at $21^{\circ} \mathrm{N}$ (31) (see Table 1). The strains were taken from seawater-agar spread plates which were prepared on board the ship from serial dilutions of the samples prepared immediately after subsampling of the sediments obtained by means of a box-grab sampler or a van Veen grab. The incubation temperature was $15^{\circ} \mathrm{C}$, and the incubation time varied from 8 to 17 days, depending on the date of sampling. The seawater agar of ZoBell was modified and consisted of 5 $\mathrm{g}$ of peptone, $1 \mathrm{~g}$ of yeast extract, $0.01 \mathrm{~g}$ of $\mathrm{FePO}_{4} \cdot 4 \mathrm{H}_{2} \mathrm{O}, 15$ $\mathrm{g}$ of Difco Bacto-Agar, $750 \mathrm{ml}$ of aged seawater, and $250 \mathrm{ml}$ of distilled water (42). The $\mathrm{pH}$ was adjusted to 7.6. The star-shaped-aggregate-forming isolates consisted of $55 \mathrm{~A}$. atlanticum and $19 \mathrm{~A}$. meteori strains, as identified by phenotypic characteristics. Strains of both species from different depths were selected for additional phenotypic and genotypic studies and were compared with reference strains from the American Type Culture Collection, Rockville, Md., and the German Collection of Microorganisms, Braunschweig, Germany (Table 1).
Phenotypic tests. Common identification tests were performed in seawater media at $20^{\circ} \mathrm{C}$ as described previously (33). Nitrate reduction to nitrite and gas was determined in mineral media prepared with artificial seawater (34). The ability to grow under anaerobic conditions was tested with the OXOID Anaerobic System. In order to absorb the excess carbon dioxide which is developed in this anaerobic system, three test tubes with $10 \mathrm{ml}$ of saturated $\mathrm{KOH}$ solutions were placed in the anaerobic jars. Susceptibility to antibiotics was tested on seawater-agar plates with OXOID sensitivity disks, and the tests for DNase activity were performed with OXOID DNase-agar.

The utilization of organic substrates as sole sources of carbon and energy was studied in microtiter plates by means of a multipoint inoculator; three wells were used for each strain. Turbidity was taken as an indicator for substrate utilization and measured with a microtiter plate photometer after $2,4,6$, and 8 weeks of incubation at $20^{\circ} \mathrm{C} \mathrm{(32).}$

Isolation of DNA. DNA was isolated from cells grown in seawater broth containing the same concentrations of peptone, yeast extract, and $\mathrm{FePO}_{4} \cdot 4 \mathrm{H}_{2} \mathrm{O}$ as the seawater agar and purified according to the method of Marmur (28). Because of copious slime production by the cells, the lysis procedure had to be modified. Depending on the strain, several milliliters of sodium lauryl sulfate solution (25\%) was applied for about $1 \mathrm{~h}$ at $65^{\circ} \mathrm{C}$. Then the cell suspensions were cooled to 25 to $30^{\circ} \mathrm{C}$ and subsequently incubated for an additional 1 to $3 \mathrm{~h}$ with $0.8 \mathrm{mg}$ of lysozyme (Merck 5281) and $0.15 \mathrm{mg}$ of proteinase $\mathrm{K}$ (Merck 24568) per ml. For strains 1373 and ATCC $25655^{\mathrm{T}}, 0.8 \mathrm{mg}$ of lysozyme, $0.8 \mathrm{mg}$ of protease (Sigma P 6911), $0.4 \mathrm{mg}$ of $\alpha$-amylase (Merck 1329), and $0.5 \mathrm{mg}$ of $\beta$-glucosidase (Sigma G 0395) were added per $\mathrm{ml}$, and for strain $1474,0.8 \mathrm{mg}$ of lysozyme and $0.5 \mathrm{mg}$ of $\beta$-glucosidase were added per $\mathrm{ml}$.

DNA base composition. The $\mathrm{G}+\mathrm{C}$ content of the DNA was determined from the midpoint value of the thermal denaturation profile (29) obtained with a Gilford model 250 spectrophotometer equipped with a Gilford model 2527 thermoprogrammer. The $\mathrm{G}+\mathrm{C}$ content of the DNA was calculated from the melting temperature by using the equation of De Ley (6). DNA from Escherichia coli K-12, which has a melting temperature of $90.6^{\circ} \mathrm{C}$ in standard saline citrate (SSC) buffer (6), was used as a reference.

DNA-DNA hybridization. DNA hybridization was determined from renaturation rates according to the methods and conditions reported by De Ley et al. (8) and Gillis et al. (10). The DNA was isolated and purified as described above and then dialyzed against 2 liters of double-strength SSC for 3 days at $4^{\circ} \mathrm{C}$. The buffer was replaced by fresh buffer solutions after 24 and again after $48 \mathrm{~h}$. After dialysis, the DNA solutions $\left(A_{260}\right.$, approximately 2.0 ) were passed three times through a French pressure cell at $11 \times 10^{7} \mathrm{~Pa}$. The DNA concentrations of every two samples to be hybridized were adjusted to an $A_{260}$ of 1.3 in $2 \times \mathrm{SSC}$, which corresponds to $65 \mu \mathrm{g}$ of DNA per ml. The renaturation experiments were performed in a Gilford model 250 spectrophotometer equipped with a Gilford model 2527 thermoprogrammer. For the measurements, a Gilford thermocuvette containing the two DNA samples, a 1:1 mixture of both DNA solutions, and $2 \times$ SSC as a blank were used.

The DNA samples were denatured by raising the temperature to $105^{\circ} \mathrm{C}$ for $20 \mathrm{~min}$. For renaturation, the temperature was then rapidly adjusted to $65^{\circ} \mathrm{C}$. The decrease in absorbance, which reached linearity after a few minutes, was recorded for $40 \mathrm{~min}$. Renaturation rates were determined from the renaturation curves. The degrees of DNA-DNA 
binding were calculated from the renaturation rates with equation 20 of De Ley et al. (8). Two to five renaturation assays were performed for each combination of strains.

LMW-RNA profiles. This genotyping technique uses the stable low-molecular-weight (LMW) RNAs (5S rRNA and tRNA) of bacteria for taxonomic grouping of the organisms (16-18). The cells were grown on seawater-agar plates. Biomass for extraction of total RNA was harvested from single agar plates by scraping off all colonies with a soft rubber spatula and dissolving the material in $1 \mathrm{ml}$ of buffer (50 mM sodium acetate, $10 \mathrm{mM}$ EDTA, pH 5.1). The biomass was collected in microcentrifuge tubes by centrifugation, and the pellet was stored at $-20^{\circ} \mathrm{C}$ before RNA extraction. Total RNA was extracted by hot phenol and subsequently precipitated with ethanol. This crude total RNA was purified and enriched for the LMW fraction by using Qiagen 100 pack according to the manufacturer's protocol (Diagen Corp., Düsseldorf, Germany). Purified RNA ( 2 to $3 \mu \mathrm{g}$ ) was subjected to high-power gel electrophoresis under denaturing conditions (11). The specific gel used consisted of $10 \%$ acrylamide with $7 \mathrm{M}$ urea and a running buffer of $100 \mathrm{mM}$ Tris, $83 \mathrm{mM}$ boric acid, and $1 \mathrm{mM}$ EDTA at pH 8.5. Running conditions were $3 \mathrm{~h}$ at $2,400 \mathrm{~V}$ and $60^{\circ} \mathrm{C}$. After electrophoresis, RNA bands were visualized by silver staining according to Kolodny (26). More-technical information on the LMW-RNA profile method was given previously (16).

\section{RESULTS}

The 74 marine star-shaped-aggregate-forming bacteria from sediments of the northwestern African upwelling area consisted of $55 \mathrm{~A}$. atlanticum and $19 \mathrm{~A}$. meteori strains. Seven $A$. atlanticum and five $A$. meteori strains from different depths were selected for further taxonomic examination and compared with star-shaped-aggregate-forming reference strains originally isolated from the Baltic Sea $(1,2)$ (obtained from culture collections) and with $A$. stellulatum (Table 1)

Phenotyping. (i) Morphology. The cells of A. stellulatum and of the isolates from the Baltic Sea and the northwestern African upwelling region were gram-negative, regular, clubshaped or dumb-bell-shaped rods or coccobacilli and sometimes straight or curved filaments. They occurred singly, in pairs and short chains, or in irregular clusters or starlike aggregates which developed predominantly at the end of the logarithmic growth phase in seawater broth. However, starshaped-aggregate formation cannot always be observed; it seems to be dependent on the physiological state of the cells. Figure 1 shows star-shaped-aggregation formation in $A$. atlanticum $1480^{\mathrm{T}}$ (Fig. 1a) and A. meteori $1513^{\mathrm{T}}$ (Fig. 1b) after incubation in seawater broth for 4 days at $20^{\circ} \mathrm{C}$.

(ii) Physiological and biochemical tests. The physiological and biochemical characteristics of all strains are presented in Table 2. Some strains were able to grow under reduced oxygen tensions and are therefore characterized as weakly positive in the test for anaerobic growth. Most of the northeastern Atlantic Ocean isolates required seawater media for growth; only $13 \mathrm{~A}$. atlanticum and $10 \mathrm{~A}$. meteori strains showed slight but significantly reduced growth in media prepared without seawater. The brackish-water-type Baltic Sea isolates were usually capable of weak growth in freshwater media, but their growth was stimulated in seawater broth. In contrast, terrestrial agrobacteria do not require seawater media, and some strains are even inhibited by sea salts (unpublished data).
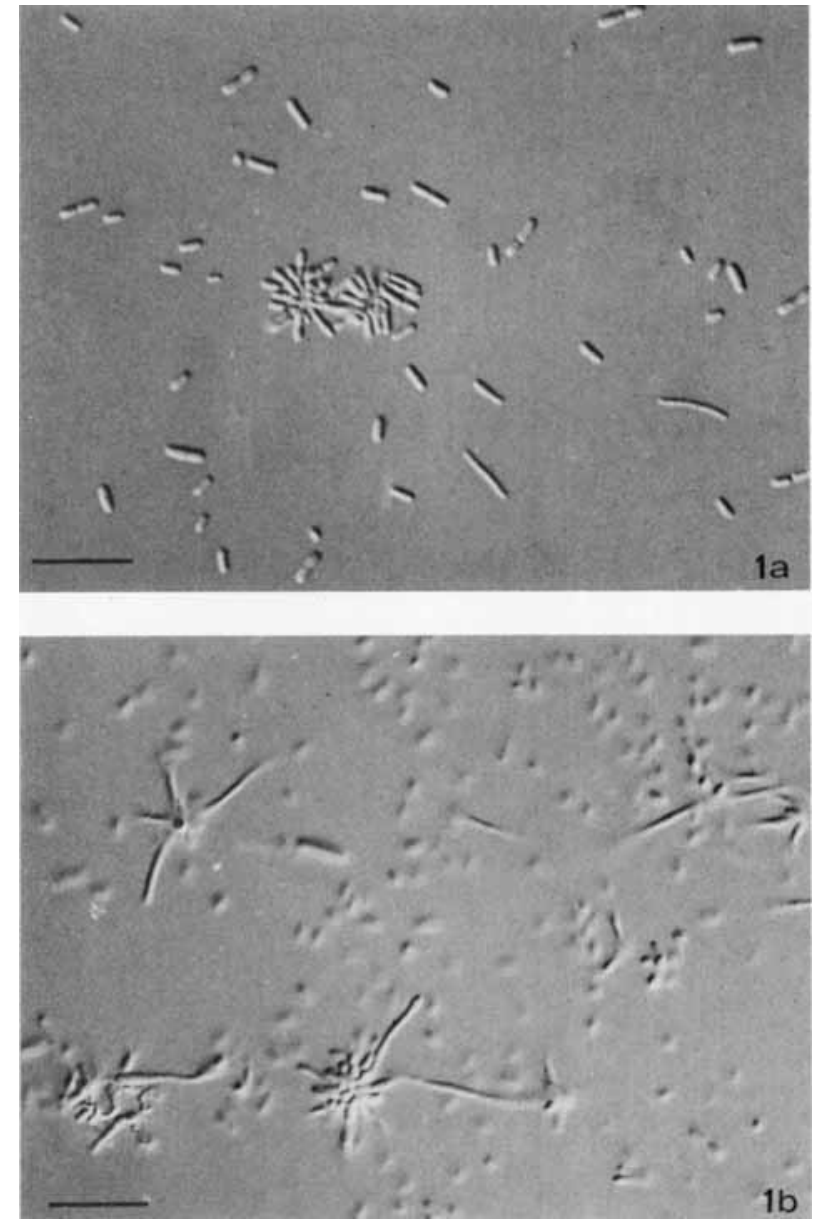

FIG. 1. Star-shaped-aggregate formation by A. atlanticum $1480^{\mathrm{T}}$ (a) and $A$. meteori $1513^{\mathrm{T}}$ (b) after incubation in seawater broth for 4 days at $20^{\circ} \mathrm{C}$. Bars $=10 \mu \mathrm{m}$ (interference-contrast microscopy).

In contrast to terrestrial agrobacteria, the marine strains showed negative results in tests for aerobic acid production from carbohydrates when incubated as usual for a few days up to about 2 weeks. The marine strains may show positive or weakly positive results only after prolonged incubation and, in spite of good growth, not earlier than 4 to 6 weeks (Table 2). Ahrens and Rheinheimer (2) observed acid production from carbohydrates by their strains only after 8 to 10 weeks of incubation.

For the utilization of carbohydrates, carboxylic acids, alcohols, amino acids, and putrescine by the marine strains listed in Table 1 , the test results obtained after 4 weeks of incubation at $20^{\circ} \mathrm{C}$ were used (Table 3). However, $86 \%$ of the positive reactions were already detected after 2 weeks. A few positive results occurring after 6 or 8 weeks of incubation were regarded as negative in Table 3. Strain $A$. ferrug ineum ATCC $25652^{\mathrm{T}}$ gave negative results in all substrate utilization tests at $20^{\circ} \mathrm{C}$ but was able to utilize propionate, fumarate, succinate, lactate, glycerol, and glutamate at $4^{\circ} \mathrm{C}$ within 4 to 6 weeks, thus showing behavior similar to that of some deep-sea bacteria described previously (32).

Genotyping. (i) DNA base compositions. The DNA base ratios of the northeastern Atlantic Agrobacterium strains and most of the Baltic Sea species were in the range of 54 to 
TABLE 2. Phenotypic characteristics of marine Agrobacterium species and of some marine star-shaped-aggregate-forming bacteria of uncertain taxonomic position

\begin{tabular}{|c|c|c|c|c|c|c|c|c|c|c|c|c|}
\hline \multirow[b]{2}{*}{ Characteristic $^{a}$} & \multicolumn{12}{|c|}{ No. of strains with positive or slightly positive test results ${ }^{b}$} \\
\hline & 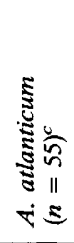 & 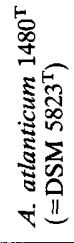 & 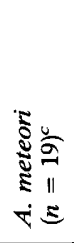 & 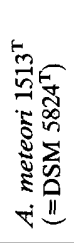 & 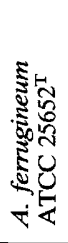 & 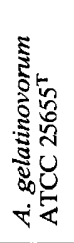 & 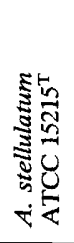 & 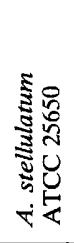 & 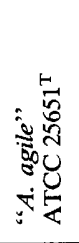 & 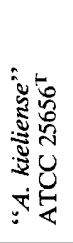 & 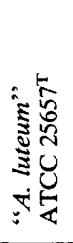 & 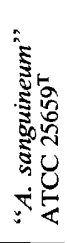 \\
\hline \multicolumn{13}{|l|}{ Colony pigmentation } \\
\hline Colorless, beige, yellowish & 55 & + & 17 & + & - & + & + & + & + & + & - & - \\
\hline Brown, light brown, brown center & 0 & - & 2 & - & + & + & - & + & $(+)$ & - & _- & - \\
\hline Yellow & 0 & - & 0 & - & - & - & - & - & - & - & + & - \\
\hline Red & 0 & - & 0 & - & - & - & - & - & - & - & - & + \\
\hline Motility & 3 & - & 10 & + & + & + & + & + & + & + & + & + \\
\hline Facultatively anaerobic & 0 & - & 1 & - & - & - & $(+)$ & $(+)$ & $(+)$ & - & - & - \\
\hline Growth without seawater base & 13 & - & 10 & $(+)$ & + & - & $(+)^{d}$ & $(+)$ & $(+)$ & $(+)$ & - & $(+)$ \\
\hline Growth at $5^{\circ} \mathrm{C}, 7$ days & 28 & - & 13 & $(+)$ & + & $(+)$ & $(+)$ & $(+)$ & ND & + & - & - \\
\hline Growth at $37^{\circ} \mathrm{C}, 7$ days & 7 & - & 6 & - & - & - & + & + & ND & - & - & $(+)$ \\
\hline Catalase & 54 & + & 12 & - & + & + & + & + & + & + & + & + \\
\hline $\mathrm{H}_{2} \mathrm{~S}$ production from cysteine & 0 & - & 2 & - & - & - & ND & - & - & + & - & - \\
\hline \multicolumn{13}{|l|}{ Susceptible to: } \\
\hline Penicillin G, 2U & 46 & - & 14 & + & ND & ND & ND & ND & ND & ND & ND & ND \\
\hline Oxytetracycline, $5 \mu \mathrm{g}$ & 55 & + & 16 & + & ND & ND & ND & ND & ND & ND & ND & ND \\
\hline \multicolumn{13}{|l|}{ Hydrolysis of: } \\
\hline Gelatin & 0 & - & 2 & - & - & + & - & - & - & - & - & - \\
\hline Starch & 0 & - & 1 & - & - & - & - & - & - & - & - & - \\
\hline Arginine dihydrolase & 7 & - & 6 & - & ND & ND & ND & ND & ND & ND & ND & ND \\
\hline Urease & 0 & - & 8 & - & - & ND & ND & ND & ND & ND & ND & ND \\
\hline Lipase (tributyrin) & 14 & - & 11 & + & ND & ND & ND & ND & ND & ND & ND & ND \\
\hline Nitrate reduction to nitrite & 51 & + & 14 & + & - & + & - & - & + & - & - & - \\
\hline Nitrate reduction to gas & 55 & + & 0 & - & - & - & + & + & + & - & - & - \\
\hline \multicolumn{13}{|l|}{$\begin{array}{l}\text { Aerobic acid production after } 4-6 \\
\text { wk (not earlier) from: }\end{array}$} \\
\hline Glucose & 52 & + & 10 & - & + & - & - & - & - & - & - & - \\
\hline Arabinose & 46 & + & 2 & - & ND & ND & ND & ND & ND & ND & ND & ND \\
\hline Fructose & 7 & - & 5 & - & + & - & ND & $(+)$ & - & $(+)$ & - & - \\
\hline Glycerol & 29 & + & 5 & - & + & + & ND & $(+)$ & $(+)$ & + & - & - \\
\hline Lactose & 1 & - & 1 & - & ND & ND & ND & ND & ND & ND & ND & ND \\
\hline Maltose & 11 & + & 7 & - & + & - & - & + & - & $(t)$ & - & - \\
\hline Mannitol & 0 & - & 2 & - & ND & ND & $-^{d}$ & ND & ND & ND & ND & ND \\
\hline Sucrose & 12 & + & 7 & - & ND & ND & ND & ND & ND & ND & ND & ND \\
\hline Xylose & 32 & + & 3 & - & + & - & ND & - & - & + & - & 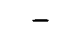 \\
\hline
\end{tabular}

${ }^{a}$ The cells of all strains were gram-negative, regular, club-shaped or dumb-bell-shaped rods or coccobacilli 0.6 to $1.2 \mu \mathrm{m}$ by 1.0 to $4.0 \mu \mathrm{m}$. Starlike aggregates were common but not always present. Motile strains were peritrichous or degenerately peritrichous, with 1 to 8 flagella; only " $A$. agile" ATCC $25651^{\mathrm{T}}$ was polarly flagellated, with 1 to 3 flagella. Optimum growth temperatures were between 20 and $30^{\circ} \mathrm{C}$. Oxidase positive. All strains were negative in the following tests: indole, methyl red, Voges-Proskauer, susceptibility to $10 \mu \mathrm{g}$ of pteridine $\mathrm{O} / 129$, lysine and ornithine decarboxylase, and hydrolysis of casein, chitin, and alginate. Forty-five $A$. atlanticum and $18 \mathrm{~A}$. meteori strains were tested for susceptibility to $50 \mu \mathrm{g}$ of furazolidone and $10 \mu \mathrm{g}$ of chloramphenicol (all strains positive) and for DNAse activity (all but 2 strains negative). The following characteristics of strains ATCC $15215^{\mathrm{T}}, \mathrm{ATCC}^{25650}, \mathrm{ATCC} 25651^{\mathrm{T}}, \mathrm{ATCC} 25652^{\mathrm{T}}$, ATCC $25655^{\mathrm{T}}$ ATCC $25656^{\mathrm{T}}$, ATCC $25657^{\mathrm{T}}$, and ATCC $25659^{\mathrm{T}}$ were taken from Ahrens (1) and Ahrens and Rheinheimer (2): growth without seawater base, $\mathrm{H}_{2} \mathrm{~S}$ production from cysteine, gelatin hydrolysis, and acid production from glucose, fructose, glycerol, maltose, and xylose. For these reference strains, no results were reported for arginine dihydrolase, lysine and ornithine decarboxylase, and susceptibility to pteridine $0 / 129$.

${ }^{b}$ Symbols: + , positive; $(+)$, weakly positive; - , negative; ND, not tested or not reported.

$c$ Number of strains tested.

${ }^{d}$ According to Stapp and Knösel (41).

$59 \mathrm{~mol} \% \mathrm{G}+\mathrm{C}$. Quite different guanine-plus-cytosine ratios of 63 and $48 \mathrm{~mol} \%$ were found for " $A$. sanguineum" and " $A$. kieliense," respectively (Table 4), indicating that these species are not closely related to the other strains.

(ii) DNA-DNA relatedness. The $A$. atlanticum strains are grouped together by their DNA-DNA homology values of 56 to $88 \%$ (Table 5). A. meteori $1513^{\mathrm{T}}$ is distinct from all the other strains and represents a separate species. A. stellulatum ATCC $15215^{\mathrm{T}}$ and $A$. stellulatum ATCC 25650 (received as $A$. aggregatum) have $106 \%$ DNA homology and are therefore identical at the species level. $A$. gelatinovorum
ATCC $25655^{\mathrm{T}}$ showed DNA-DNA homology values of 37 and $42 \%$ with $A$. atlanticum strains, indicating closer relationships than were usually found between the marine $\mathrm{Ag}$ robacterium species (Table 5).

(iii) LMW-RNA profiles. High-resolution electrophoretic analysis of LMW RNAs (5S rRNA and tRNA) for genotypic identification of eubacteria has recently been developed $(16-18)$. By using reference strains from culture collections, it was shown that bacterial strains with identical LMW-RNA band patterns are of the same genotype at the species level. Furthermore, it was possible to find genus-specific LMW- 
TABLE 3. Utilization of organic substrates as sole carbon and energy sources by selected marine Agrobacterium species and some marine star-shaped-aggregate-forming bacteria of uncertain taxonomic position

\begin{tabular}{|c|c|c|c|c|c|c|c|c|c|c|c|c|c|c|}
\hline \multirow[b]{2}{*}{ Characteristic $^{a}$} & \multicolumn{3}{|c|}{ A. atlanticum } & \multicolumn{3}{|c|}{ A. meteori } & \multirow[b]{2}{*}{ 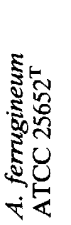 } & \multirow[b]{2}{*}{ 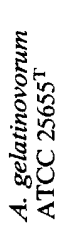 } & \multirow[b]{2}{*}{ 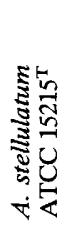 } & \multirow[b]{2}{*}{ 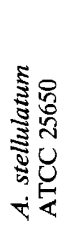 } & \multirow[b]{2}{*}{ 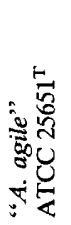 } & \multirow[b]{2}{*}{ 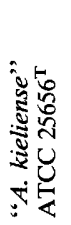 } & \multirow[b]{2}{*}{ 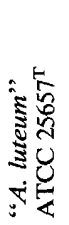 } & \multirow[b]{2}{*}{ 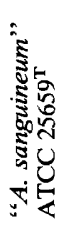 } \\
\hline & 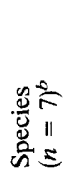 & 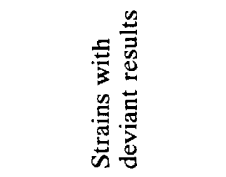 & 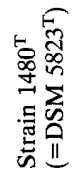 & 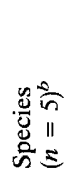 & 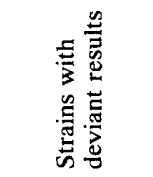 & 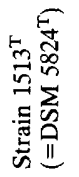 & & & & & & & & \\
\hline \multicolumn{15}{|l|}{ Carbohydrate utilization } \\
\hline L-Arabinose & - & & - & - & & - & - & - & + & + & + & - & - & - \\
\hline Cellobiose & + & 1554 & + & - & & - & - & - & + & + & + & - & - & + \\
\hline D-Galactose & + & 1554 & + & - & & - & - & - & + & + & + & - & - & - \\
\hline Gluconate & + & $1373,1474,1554$ & + & - & & - & - & - & + & + & + & - & - & - \\
\hline D-Glucose & + & 1554 & + & - & & - & - & - & + & + & + & - & - & + \\
\hline Maltose & + & 1554 & + & - & & - & - & - & + & + & + & - & - & - \\
\hline D-Mannose & + & 1554 & + & - & & - & - & - & + & + & + & - & - & - \\
\hline D-Ribose & - & $1474,1532,1546$ & - & - & & - & - & - & + & + & + & - & - & - \\
\hline Sucrose & + & 1554 & + & - & & - & - & - & + & + & + & - & - & + \\
\hline Salicin & - & & - & - & & - & - & - & + & + & + & - & - & - \\
\hline Trehalose & + & 1554 & + & - & & - & - & - & + & + & + & - & - & - \\
\hline D-Xylose & + & 1373,1554 & + & - & & - & - & - & + & + & + & - & - & - \\
\hline \multicolumn{15}{|l|}{ Carboxylic acid utilization } \\
\hline $\mathrm{Na}$ acetate & + & 1554 & + & - & & - & - & + & + & + & + & - & - & + \\
\hline Na propionate & + & 1554 & + & - & & - & - & + & + & + & + & - & + & + \\
\hline Fumarate & + & & + & - & & - & - & + & + & + & + & - & - & + \\
\hline Succinate & + & & + & - & & - & - & + & + & + & + & - & - & - \\
\hline Citrate & + & & + & - & & - & - & - & + & + & + & - & - & - \\
\hline DL-3-Hydroxybutyrate & + & 1554 & + & - & & - & - & + & + & + & + & - & + & + \\
\hline Lactate & + & 1554 & + & - & 1479,1503 & - & - & + & + & + & + & - & - & - \\
\hline Pyruvate & + & & + & - & & - & - & + & + & + & + & - & - & + \\
\hline \multicolumn{15}{|l|}{ Alcohol utilization } \\
\hline Glycerol & + & 1373 & + & - & & - & - & - & + & + & + & - & - & - \\
\hline Mannitol & + & 1474,1554 & + & - & & - & - & - & + & + & + & - & - & - \\
\hline Sorbitol & - & & - & - & & - & - & - & + & + & + & - & - & - \\
\hline \multicolumn{15}{|l|}{ Amino acid utilization } \\
\hline L-Alanine & + & & + & - & & - & - & + & + & + & + & - & - & - \\
\hline L-Arginine & + & 1373,1554 & + & - & & - & - & + & + & + & + & - & - & - \\
\hline L-Aspartate & + & $1373,1474,1554$ & + & - & & - & - & - & + & + & + & - & - & - \\
\hline L-Glutamate & + & & + & - & & - & - & - & + & + & + & - & + & + \\
\hline L-Histidine & - & 1373 & - & - & & - & - & - & + & + & + & - & - & - \\
\hline L-Lysine & + & 1373,1474 & + & - & & - & - & + & - & - & + & - & - & - \\
\hline L-Ornithine & + & 1373 & + & - & & - & - & + & + & + & + & - & - & - \\
\hline Putrescine utilization & + & 1373,1554 & + & - & & - & - & + & + & + & + & - & - & - \\
\hline
\end{tabular}

${ }^{a}$ Incubation was for 4 weeks at $20^{\circ} \mathrm{C}$. None of the strains utilized adipate, $p$-hydroxybenzoate, or quinate.

${ }^{b}$ Number of strains tested.

RNA bands if the different species were phylogenetically closely enough related (17).

All LMW-RNA profiles of the strains given in Table 1 have been studied, and representative results are shown in Fig. 2. The following groups of strains showed identical LMW-RNA profiles in every band: (i) $A$. stellulatum ATCC $15215^{\mathrm{T}}$ and ATCC $25652^{\mathrm{T}}$ (Fig. 2, lanes a and $\mathrm{b}$, respectively); (ii) $A$. atlanticum $1480^{\mathrm{T}}, 1474,1532,1546$ (Fig. 2, lanes e through $\mathrm{h}$, respectively), 1373, 1501, and 1554 (data not shown); and (iii) A. meteori $1513^{\mathrm{T}}, 1479,1503$ (Fig. 2, lanes $i$ through $\mathrm{k}$, respectively), 1496, and 1504 (data not shown). These findings indicate that these three groups of strains are all identical at the species level. This identity was confirmed by comparing gel scans of the single strains comparable to the ones given for the individual species in Fig. 3A. The five Agrobacterium species $A$. atlanticum, $A$. ferrugineum, $A$. gelatinovorum, $A$. meteori, and $A$. stellulatum have individual LMW-RNA band patterns which significantly differed from each other by at least one band position (Fig. 2 and 3A). Bands of specific discriminative value between species are labeled in Fig. 2 and 3A to show the differences between $A$. atlanticum and $A$. gelatinovorum on the one side (arrow at the 5S rRNA band at 117 nucleotides in Fig. 2 and 3A, lane d) and between $A$. atlanticum and $A$. meteori on the other side (arrow at the different class 2 tRNA band in Fig. 2 and $3 \mathrm{~A}$, lane i).

For the genotypic grouping of a set of strains as a taxon above the rank of species, identical LMW-RNA bands or banding patterns have to be found in all the individual species of that taxon (18). This can best be done with the help of normalized gel scans that indicate the precise position of the bands and are also able to resolve the very strong bands in the class 1 tRNA. As can be seen in Fig. 3A, there are two major bands, connected by dashed lines, in each of the tRNA classes that occur in all five species. The 5S rRNA region is characterized by two bands at 127 and 117 nucleotides (nt) except in $A$. stellulatum, which displays only the 117-nt band. The second 5S rRNA band of $A$. atlanticum and $A$. meteori has a size of $116 \mathrm{nt}$, indicating a loss of one nucleotide at one of the molecule's ends or some other 
TABLE 4. DNA base compositions of marine Agrobacterium strains and of some other marine star-shaped-aggregateforming bacteria

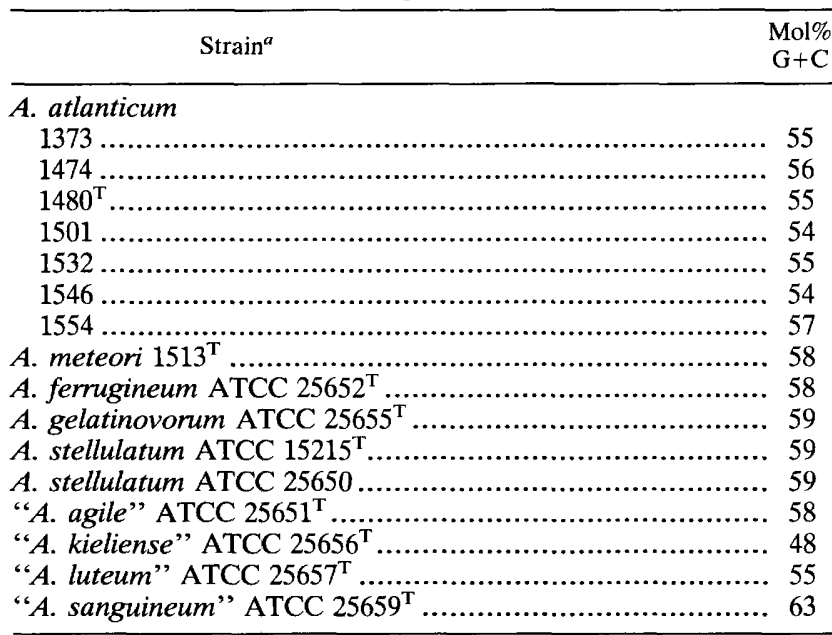

${ }^{a} \mathrm{G}+\mathrm{C}$ ratios as reported in the literature: A. ferrugineum ATCC $25652^{\mathrm{T}}$, $60 \mathrm{~mol} \%$ (1); A. gelatinovorum ATCC $25655^{\mathrm{T}}, 57.6 \mathrm{~mol} \%$ (9); A. stellulatum ATCC 25650, $58.7 \mathrm{~mol} \%(9)$; "A. agile" ATCC $25651^{\mathrm{T}}, 57.1$ (9) and $59(1)$ mol\%; "A. kieliense" ATCC $25656^{\mathrm{T}}, 50.6 \mathrm{~mol} \%$ (9); " $A$. luteum" ATCC $25657^{\mathrm{T}}, 57 \mathrm{~mol} \%$ (1); and “ $A$. sanguineum" ATCC $25659^{\mathrm{T}}, 64 \mathrm{~mol} \%$ (1).

size-disturbing effects like hairpin formation. The greatest resemblance between the gel scans can be seen with $A$. gelatinovorum and $A$. atlanticum. These two species can be distinguished only by the difference in the second 5S rRNA position (arrow, Fig. 3A, lane d). The least similar to all the other of the five species is $A$. stellulatum because it lacks the first 5S rRNA band and because of the differences in the second part of the class 1 tRNA. Overall, the gel scans of the five different marine Agrobacterium species share enough bands and band patterns to group them into one taxon above species rank. This high degree of similarity among these five species can also be judged from all the differences seen in the gel scans of the second five species, shown in Fig. 3B. Here,

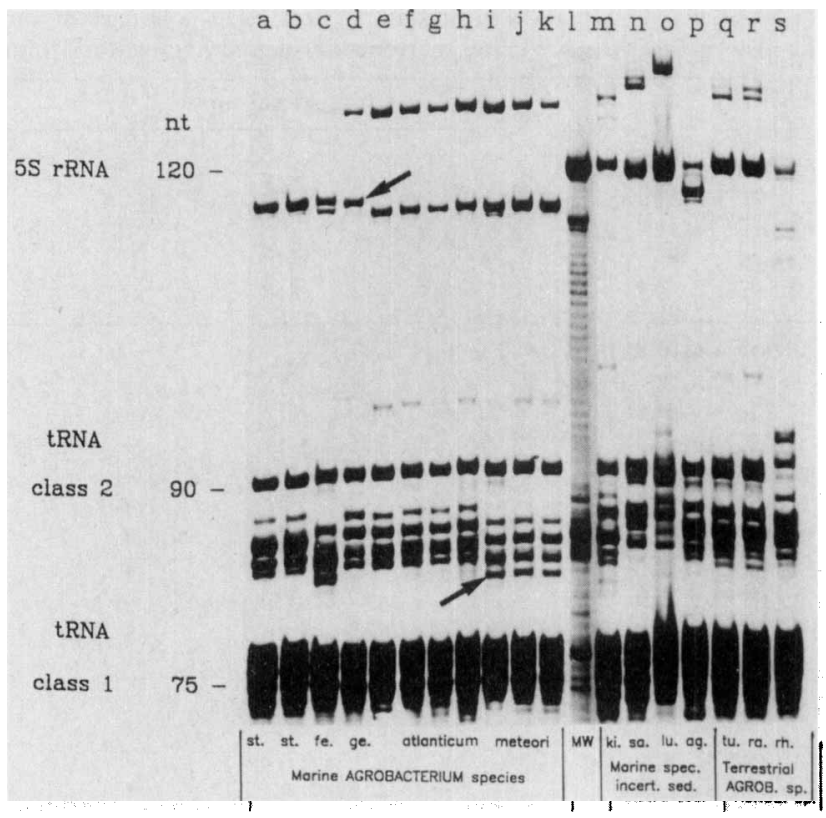

FIG. 2. LMW-RNA profiles of the investigated strains. Arrows indicate bands of specific discriminative value for different marine species. Lanes: a through k, marine Agrobacterium spp.; a, $A$. stellulatum ATCC $15215^{\mathrm{T}} ; \mathrm{b}, A$. stellulatum ATCC $25652^{\mathrm{T}} ; \mathrm{c}, A$. ferrugineum ATCC $25652^{\mathrm{T}}$; d, A. gelatinovorum ATCC $25655^{\mathrm{T}}$; e, A. atlanticum $1480^{\mathrm{T}} ; \mathrm{f}, A$. atlanticum $1474 ; \mathrm{g}$, A. atlanticum $1532 ; \mathrm{h}$, A. atlanticum $1546 ; \mathrm{i}, A$. meteori $1513^{\mathrm{T}} ; \mathrm{j}, A$. meteori $1479 ; \mathrm{k}, A$. meteori 1503 ; 1 , molecular weight standards (5S rRNA hydrolysate, tRNA $^{\text {Tyr }}$, and tRNA ${ }^{\text {Phe }}$ from $E$. coli); $\mathrm{m}$ through $\mathrm{p}$, marine species incertae sedis; $\mathrm{m}$, " $A$. kieliense" ATCC $25656^{\mathrm{T}}$; n, "A. sanguineum" ATCC $25659^{\mathrm{T}}$; o, “A. luteum" ATCC $25657^{\mathrm{T}}$; $\mathrm{p}$, “ $A$. agile" ATCC $25651^{\mathrm{T}}$; q through s, terrestrial Agrobacterium species; q, A. tumefaciens DSM $30205^{\mathrm{T}} ; \mathrm{r}$, A radiobacter DSM $30147^{\mathrm{T}}$, $\mathrm{s}, A$. rhizogenes DSM $30148^{\mathrm{T}}$. Abbreviations at bottoms of lanes are of species names.

TABLE 5. DNA-DNA homology between pairs of marine star-shaped-aggregate-forming bacteria

\begin{tabular}{|c|c|c|c|c|c|c|c|c|c|c|c|c|c|}
\hline \multirow[b]{2}{*}{ Strain } & \multicolumn{13}{|c|}{$\%$ Homology $^{a}$} \\
\hline & 离 & $\stackrel{m}{9}$ & 売 & ్ֶ & 导 & 芯 & $\stackrel{\vec{m}}{\vec{n}}$ & 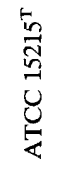 & 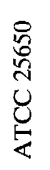 & 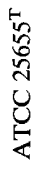 & 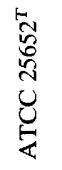 & 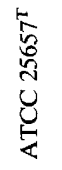 & 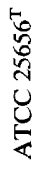 \\
\hline \multicolumn{14}{|l|}{ A. atlanticum } \\
\hline $1480^{\mathrm{T}}$ & 103 & & & & & & & & & & & & \\
\hline 1373 & 72 & 98 & & & & & & & & & & & \\
\hline 1474 & 71 & 77 & ND & & & & & & & & & & \\
\hline 1532 & 62 & 79 & 72 & ND & & & & & & & & & \\
\hline 1546 & 67 & 56 & 88 & 82 & ND & & & & & & & & \\
\hline 1554 & 72 & 59 & 68 & 70 & 68 & ND & & & & & & & \\
\hline A. meteori $1513^{\mathrm{T}}$ & 27 & 22 & 29 & 34 & 24 & 22 & 100 & & & & & & \\
\hline A. stellulatum ATCC $15215^{\mathrm{T}}$ & 32 & 25 & & & & & 24 & ND & & & & & \\
\hline A. stellulatum ATCC 25650 & 29 & 21 & & & & & 30 & 106 & 97 & & & & \\
\hline A. gelatinovorum ATCC $25655^{\mathrm{T}}$ & 37 & 42 & & & & & 34 & 69 & 31 & 98 & & & \\
\hline A. ferrugineum ATCC $25652^{\mathrm{T}}$ & 28 & 34 & & & & & 25 & 30 & 24 & 33 & 100 & & \\
\hline "A. luteum" ATCC $25657^{\mathrm{T}}$ & 23 & 21 & & & & & 21 & 20 & 24 & 33 & 20 & 101 & \\
\hline "A. kieliense" АTCC $25656^{\mathrm{T}}$ & 27 & 24 & & & & & 21 & 34 & 24 & 20 & 30 & 26 & 98 \\
\hline
\end{tabular}

${ }^{a} \mathrm{ND}$, not determined. 

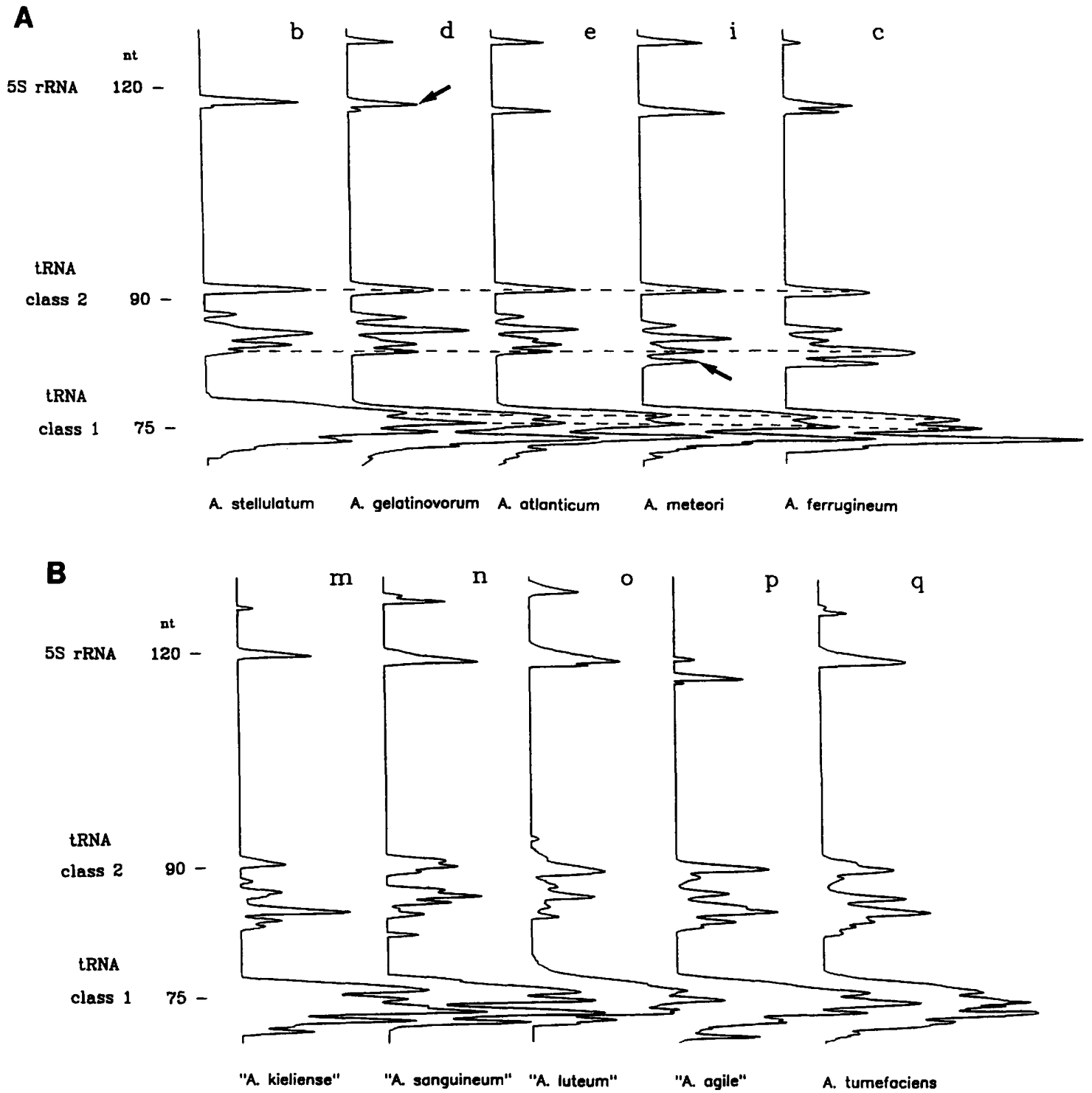

FIG. 3. Baseline-corrected gel scans of LMW-RNA profiles from all marine Agrobacterium species (A) and from A. tumefaciens and all other star-shaped-aggregate-forming species that do not belong to the marine Agrobacterium subdivision (B). Lettering of the single gel scans is as in Fig. 2 for corresponding lanes. Characteristic genus-specific peaks are connected by dashed lines. Arrows indicate bands of specific discriminative value for different species.

the 5S rRNA for the first band ranges from 128 to $131 \mathrm{nt}$, and the second band, mostly the major 5S rRNA band, is at 120 nt. The differences in the tRNA patterns are quite obvious, especially among the class 1 tRNAs, where always more bands were detected than just the three major bands detected for the first five marine Agrobacterium species.

\section{DISCUSSION}

Phenotypic characteristics. On the basis of phenotypic characteristics (Table 2), the marine star-shaped-aggregateforming bacteria from the northwestern African upwelling area could be regarded as members of the same taxon as $A$. stellulatum and the isolates from the Baltic Sea described by Ahrens (1) and Ahrens and Rheinheimer (2). To reexamine the uncertain taxonomic position of the marine star-shapedaggregate forming bacteria, additional phenotypic and geno- typic studies were performed with selected marine isolates and with reference strains from culture collections (Table 1),

On the basis of polyamine determinations, Hamana und Matsuzaki (13) grouped the very different strains "A. agile" ATCC $25651^{\mathrm{T}}$, A. stellulatum ATCC 25650 (ex A. aggregatum), A. gelatinovorum ATCC $25655^{\mathrm{T}}$, and "A. kieliense" ATCC $25656^{\mathrm{T}}$ into one type but separated $A$. stellulatum ATCC $15215^{\mathrm{T}}$ from the nearly identical strain A. stellulatum ATCC 25650 . Thus, grouping of the marine star-shapedaggregate-forming bacteria into different types by means of their polyamine contents cannot be supported by genotypic data (Tables 4 and 5 and Fig. 2 and 3).

Except for the number and arrangement of flagella, " $A$. agile" is phenotypically identical to $A$. stellulatum (Tables 2 and 3 ) but genotypically distinct from it (Fig. 2 and 3B) and probably belongs in the vicinity of the genus Pseudomonas (9). This example shows again that phenotypic characteris- 
tics alone are not sufficient for the separation of bacterial taxa. Different genotyping methods were therefore applied for further taxonomic examination of the marine starshaped-aggregate-forming bacteria.

Genotyping. (i) DNA base compositions. The DNA base compositions shown in Table 4 indicate that "A. sanguineum" and "A. kieliense" are not closely related to the other marine star-shaped-aggregate-forming strains. In general, DNA base analysis results for the reference strains are in good accord with data in the literature, which are also listed in Table 4.

(ii) DNA-DNA relatedness. With an average of $71 \%$, the DNA homology values between pairs of $A$. atlanticum strains are in the range defining a species, although strain 1373 showed only 56 or $59 \%$ reassociation with two of the other strains (Table 5). In the literature, the limit set for species varies between 60 and $80 \%$ homology $(5,12,36)$. The relatively low homology values between some $A$. atlanticum isolates are possibly due to interactions between extracellular slime produced by the strains and DNA (15). Homology values greater than $100 \%$, as found between $A$. stellulatum ATCC $15215^{\mathrm{T}}$ and A. stellulatum ATCC 25650 , should theoretically not exist but are in the range of experimental error associated with the photometrical or every other DNA-pairing method $(8,12,15,19)$. Because of the high background of about $30 \%$ in the optical method $(12,19,27)$, DNA-DNA homology values below $30 \%$ in Table 5 should be interpreted as unspecific hybridization. The two A. stellulatum strains are identical at species level, but they showed different homology values of 69 and $31 \%$ with $A$ gelatinovorum ATCC $25655^{\mathrm{T}}$ (Table 5). Although two identical strains should have the same percentage values when both are compared with a third strain (14), there are some other examples in the literature when this is not true $(14,20)$.

(iii) LMW-RNA profiles. High-resolution electrophoretic analysis of LMW RNAs (5S rRNA and tRNA) is useful for the genotypic identification of eubacteria at the species and genus levels $(17,18)$. Recently, the utility of LMW-RNA profiles was also demonstrated for the taxonomic differentiation of an extended set of gram-positive genera, including Listeria, Lactobacillus, Clostridium, and Streptococcus (39). The LMW-RNA profiles presented in Fig. 2 and 3A indicate that the five marine Agrobacterium species have enough similarities to be grouped as a separate taxon above species rank (see dashed lines in Fig. 3A). On the other hand, there are specific differences in at least one band position among the five species (see arrows in Fig. 2 and 3A), while strains of the same species show no differences at all (compare lanes e through $h$ with lanes i through $k$ in Fig. 2). The formation of a separate taxon for the five strains of marine agrobacteria is further supported by their major differences from all other marine star-shaped-aggregateforming species, the true agrobacteria (compare lanes a through $\mathrm{k}$ with lanes $\mathrm{m}$ through $\mathrm{s}$ in Fig. 2 and Fig. $3 \mathrm{~A}$ with 3B), and other phenotypically related genera like Alcaligenes and Deleya (17). Furthermore, "A. agile," "A. kieliense," "A. luteum," and "A. sanguineum" have LMWRNA profiles so different from those of the five other marine star-shaped-aggregate formers and of "true" agrobacteria (Fig. 2 and 3) that they cannot be included in either of these taxonomic groups.

The DNA-DNA homology data (Table 5) are consistent with the LMW-RNA profile results at the species level. All A. atlanticum strains have homology values of $>56 \%$, with an average of $71 \% \pm 8 \%$ (standard deviation), clearly indicating the formation of a species; the high DNA-DNA homology between the two A. stellulatum strains also provides evidence for identity at the species level. At the genus level, the close relationship of $A$. gelatinovorum with $A$. atlanticum (Fig. 2 and $3 \mathrm{~A}$ ) is supported by DNA-DNA homologies of 37 and $42 \%$ (Table 5).

Taxonomy. The marine star-shaped-aggregate-forming bacteria isolated from the Baltic Sea by Ahrens (1) and Ahrens and Rheinheimer (2) resembled A. stellulatum and were therefore described as new Agrobacterium species. Because of the questionable relationships of these isolates to terrestrial agrobacteria, Ahrens withdrew this proposal (3). The species names of the marine isolates were therefore not included on the Approved Lists of Bacterial Names (38) and have no standing in bacterial nomenclature. The exclusion of these species from the genus Agrobacterium was further supported by DNA-rRNA hybridization experiments between true agrobacteria and the marine strains except $A$. stellulatum and "A. sanguineum" (9).

The genotypic data presented in Fig. 2 and 3 have shown that five of the marine star-shaped-aggregate-forming species have enough similarities to be grouped as a distinct taxon apart from genus Agrobacterium. For the present, however, it does not seem appropriate to create a new genus for this group of bacteria because there are not enough distinctive phenotypic characters to separate the marine strains from genus Agrobacterium (Table 6). The only distinguishing characteristics that could be found for these two taxonomic groups of bacteria were that the marine strains required seawater base or showed preferential growth in seawater media and that acid production from carbohydrates was negative or, only after incubations longer than 4 to 6 weeks, weakly positive.

Until more taxonomic data are available, we therefore propose to subdivide the genus Agrobacterium to accommodate both the terrestrial and plant pathogenic species in subdivision 1 and the marine star-shaped-aggregate-forming species in subdivision 2 . An example for subdividing a genus to include different rRNA homology groups is the genus Pseudomonas (30). The marine subdivision of Agrobacterium comprises the new species $A$. atlanticum and $A$. meteori and the revived species $A$. ferrugineum, $A$. gelatinovorum, and $A$. stellulatum. The species name $A$. aggregatum is a later subjective synonym of $A$. stellulatum, which has priority.

Characteristics common to all species of the marine subdivision of Agrobacterium are as follows. The cells are gram-negative, regular, club-shaped or dumb-bell-shaped rods or coccobacilli 0.6 to $1.2 \mu \mathrm{m}$ wide and 1.0 to $4.0 \mu \mathrm{m}$ long. Straight or curved filaments possible. Occurring singly, in pairs and short chains, or in irregular clusters or starlike aggregates developing predominantly at the end of the logarithmic growth phase in seawater broth. Motile strains peritrichous or degenerately peritrichous, with 1 to 8 flagella. Endospores not formed. Aerobic, but some strains are able to grow under reduced oxygen tensions. Most species require media based on seawater or show preferential growth in seawater media. Optimum growth temperatures between 20 and $30^{\circ} \mathrm{C}$. Oxidase positive. Indole, methyl red, VogesProskauer, lysine and ornithine decarboxylase negative. Hydrolysis of casein, chitin, and alginate negative. Aerobic acid production from carbohydrates negative or, only after incubations longer than 4 to 6 weeks, weakly positive. The cells utilize many carbohydrates but not adipate, $p$-hydroxybenzoate, or quinate and usually produce considerable extracellular slime. $\mathrm{G}+\mathrm{C}$ content of the DNA ranges from 54 
TABLE 6. Differentiation of marine and terrestrial agrobacteria from other colorless gram-negative, peritrichously flagellated genera frequently occurring in marine environments

\begin{tabular}{|c|c|c|c|c|}
\hline \multirow[b]{2}{*}{ Characteristic } & \multicolumn{2}{|c|}{ Agrobacterium spp. ${ }^{a}$} & \multirow[b]{2}{*}{ Alcaligenes spp. ${ }^{b}$} & \multirow[b]{2}{*}{ Deleya spp. ${ }^{c}$} \\
\hline & $\begin{array}{l}\text { Subdivision } 1 \\
\left(\text { terrestrial }^{d} \text { ) }\right.\end{array}$ & $\begin{array}{l}\text { Subdivision } 2 \\
\quad \text { (marine) }\end{array}$ & & \\
\hline DNA base composition $(\mathrm{mol} \% \mathrm{G}+\mathrm{C})$ & $57-63$ & $54-59$ & $56-70$ & $52-68$ \\
\hline Rods, coccal rods, or cocci & + & + & + & + \\
\hline $\begin{array}{l}\text { Regular, club-shaped or dumb-bell-shaped } \\
\text { rods or coccobacilli }\end{array}$ & + & + & - & - \\
\hline Starlike aggregates & + & + & - & - \\
\hline $\begin{array}{l}\text { Seawater base requirement or preferential } \\
\text { growth in seawater media }\end{array}$ & - & + & - & + \\
\hline Growth under reduced oxygen tensions & + & $\mathrm{D}$ & - & - \\
\hline Nitrate or nitrite reduction to gas & D & $\mathrm{D}$ & + & - \\
\hline Urease & + & $-*$ & - & D \\
\hline \multicolumn{5}{|l|}{ Acid from: } \\
\hline Glucose & + & $-^{e}$ & D & $\mathrm{D}$ \\
\hline Arabinose & + & $-^{e}$ & ND & D \\
\hline Fructose & + & $-^{e}$ & ND & $\mathrm{D}$ \\
\hline Maltose & + & $-^{e}$ & ND & D \\
\hline Xylose & + & $-^{e}$ & D & $\mathrm{D}$ \\
\hline Habitat & $\begin{array}{l}\text { Soil, infected plant } \\
\text { material }\end{array}$ & Marine environments & $\begin{array}{l}\text { Soil, water, feces, } \\
\text { clinical specimens }\end{array}$ & Marine environments \\
\hline
\end{tabular}

${ }^{a}$ Symbols: + , positive; - , negative; ND, not determined or not reported; ${ }^{*}, 67$ of 75 tested strains were negative; D, positive and negative strains are known.

$b$ According to Kersters and De Ley (24).

${ }^{c}$ According to Baumann et al. (4) and Rüger et al. (35).

${ }^{d}$ According to Kersters and De Ley (23).

$e$, Negative or weakly positive only after incubation for more than 4 to 6 weeks.

to $59 \mathrm{~mol} \%$, as determined from thermal denaturation profiles.

Description of the marine Agrobacterium species: the physiological and nutritional properties of the species and their type strains are as presented above for the whole group. Additional characteristics are listed in Tables 2 and 3. Differential traits of the species and of the species incertae sedis are presented in Table 7 and below.

Agrobacterium atlanticum sp. nov. (at.lan'ti.cum. M.L. adj. atlanticum, pertaining to the Atlantic Ocean). Colonies are circular; flat to raised; translucent; colorless, beige, or yellowish; with mean diameter of 2 to $3 \mathrm{~mm}$. Nitrate is reduced to nitrite and gas. After 4 to 6 weeks of incubation, usually acid production from glucose, arabinose, glycerol, and xylose but not from fructose, lactose, maltose, mannitol, or sucrose. Twenty-six of 34 organic substrates are utilized by the majority of the strains. Arabinose, ribose, salicin, sorbitol, histidine, adipate, $p$-hydroxybenzoate, and quinate usually not utilized. Isolated from marine sediments of the eastern Atlantic Ocean. The type strain is strain 1480 (=DSM 5823). The G+C content of its DNA is $55 \mathrm{~mol} \%$.

Description of Agrobacterium meteori sp. nov. Agrobacterium meteori (me'te.ori. M.L. gen. n. meteori, of meteor; after the German research vessel Meteor). Colonies are circular; flat to raised; translucent; colorless, beige, or yellowish; with mean diameter of 2 to $3 \mathrm{~mm}$. Nitrate is reduced to nitrite but not to gas. Except from glucose after 4 to 6 weeks of incubation, acid usually not produced from carbohydrates. None of 34 organic substrates utilized. Isolated from marine sediments of the eastern Atlantic Ocean. The type strain is strain 1513 (=DSM 5824). The $\mathrm{G}+\mathrm{C}$ content of its DNA is $58 \mathrm{~mol} \%$.

Agrobacterium ferrugineum (ex Ahrens and Rheinheimer 1967) nom. rev. emend. Colonies are circular; flat to raised; initially translucent, colorless, or light brown; later dark brown or with brown center; with mean diameter of $2 \mathrm{~mm}$.
Nitrate not reduced to nitrite or gas. Acid produced from glucose, fructose, glycerol, maltose, and xylose after 4 to 6 weeks of incubation. None of 34 organic substrates utilized at $20^{\circ} \mathrm{C}$, but the type strain was able to utilize propionate, fumarate, succinate, lactate, glycerol, and glutamate at $4^{\circ} \mathrm{C}$ within 4 to 6 weeks. Isolated from seawater of the Baltic Sea. The type strain is strain ATCC 25652. The G+C content of its DNA is $58 \mathrm{~mol} \%$.

Agrobacterium gelatinovorum (ex Ahrens 1968) nom. rev. emend. Colonies are circular, flat to raised, initially colorless, later with brown center, mean diameter of 1 to $2 \mathrm{~mm}$. The only species capable of gelatin hydrolysis. Nitrate reduced to nitrite but not to gas. Acid produced from glycerol after 4 to 6 weeks of incubation but not from glucose, fructose, maltose, or xylose. Only 12 of 34 organic substrates utilized. Isolated from seawater of the Baltic Sea. The type strain is strain ATCC 25655. The G+C content of its DNA is $59 \mathrm{~mol} \%$.

Agrobacterium stellulatum (ex Stapp and Knösel 1954) nom. rev. emend. Colonies are circular, flat to raised, translucent, initially colorless or beige, later with brown center, mean diameter of $2 \mathrm{~mm}$. Growth under reduced oxygen tensions. Nitrate reduced to nitrite and gas. No acid produced from glucose or xylose; weak or variable acid production from fructose, glycerol, and maltose after 4 to 6 weeks of incubation. Thirty of 34 organic substrates utilized but not lysine, adipate, $p$-hydroxybenzoate, or quinate. Isolated from marine sediment and from seawater. The type strain is strain ATCC 15215. The $\mathrm{G}+\mathrm{C}$ content of its DNA is $59 \mathrm{~mol} \%$.

Species incertae sedis: the taxonomic position of " $A$. agile" is probably in the vicinity of the genus Pseudomonas (9). The remaining three marine star-shaped-aggregate-forming species, "A. sanguineum," "A. kieliense," and " $A$. luteum," were originally thought to be members of the marine subdivision of genus Agrobacterium because of their 
TABLE 7. Differentiation between marine Agrobacterium species and some other marine star-shaped-aggregate-forming bacteria of uncertain taxonomic position

\begin{tabular}{|c|c|c|c|c|c|c|c|c|c|}
\hline \multirow[b]{2}{*}{ Characteristic } & \multicolumn{9}{|c|}{ Test result ${ }^{a}$} \\
\hline & 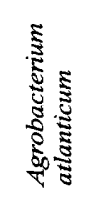 & 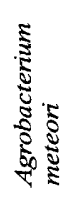 & 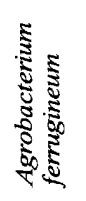 & 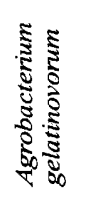 & 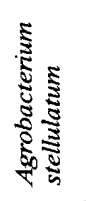 & 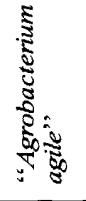 & 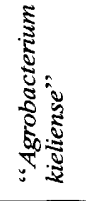 & 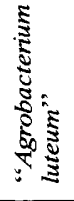 & 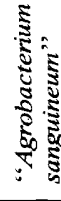 \\
\hline DNA base composition $(\mathrm{mol} \% \mathrm{G}+\mathrm{C})$ & $54-57$ & 58 & 58 & 59 & 59 & 58 & 48 & 55 & 63 \\
\hline \multicolumn{10}{|l|}{ Colony pigementation } \\
\hline Colorless, beige, yellowish & + & + & - & + & + & + & + & - & - \\
\hline Brown, light brown, brown center & - & - & + & + & - & $(+)$ & - & - & - \\
\hline Yellow & - & - & - & - & - & - & - & + & - \\
\hline Red & - & - & - & - & - & - & - & - & + \\
\hline \multicolumn{10}{|l|}{ Flagellation, if motile } \\
\hline Peritrichous, degenerately peritrichous & + & + & + & + & + & - & + & + & + \\
\hline Polar, 1-3 flagella & - & - & - & - & - & + & - & - & - \\
\hline Facultatively anaerobic & - & - & - & - & $(+)$ & $(+)$ & - & - & - \\
\hline Catalase & + & $\mathrm{D}$ & + & + & + & + & + & + & + \\
\hline $\mathrm{H}_{2} \mathrm{~S}$ production from cysteine & - & - & - & - & - & - & + & - & - \\
\hline Gelatin hydrolysis & - & - & - & + & - & - & - & - & - \\
\hline Nitrate reduction to nitrite & + & $\mathrm{D}$ & - & + & - & + & - & - & - \\
\hline Nitrite reduction to gas & + & - & - & - & + & + & - & - & - \\
\hline \multicolumn{10}{|l|}{$\begin{array}{l}\text { Aerobic acid production after } 4-6 \mathrm{wk} \\
\text { (not earlier) from: }\end{array}$} \\
\hline Glucose & + & $\mathrm{D}$ & + & - & - & - & - & - & - \\
\hline Fructose & - & D & + & - & $(+)$ & - & $(+)$ & - & - \\
\hline Glycerol & D & D & + & + & $(+)$ & $(+)$ & + & - & - \\
\hline Maltose & - & $\mathrm{D}$ & + & - & D & - & $(+)$ & - & - \\
\hline Xylose & D & - & + & - & - & - & + & - & - \\
\hline \multicolumn{10}{|l|}{ Utilization of: } \\
\hline Arabinose & - & - & - & - & + & + & - & - & - \\
\hline Cellobiose & + & - & - & - & + & + & - & - & + \\
\hline D-Glucose & + & - & - & - & + & + & - & - & + \\
\hline Salicin & - & - & - & - & + & + & - & - & - \\
\hline Trehalose & + & - & - & - & + & + & - & - & - \\
\hline Succinate & + & - & - & + & + & + & - & - & - \\
\hline Glycerol & + & - & - & - & + & + & - & - & - \\
\hline Sorbitol & - & - & - & - & + & + & - & - & - \\
\hline L-Alanine & + & - & - & + & + & + & - & - & - \\
\hline L-Glutamate & + & - & - & - & + & + & - & + & + \\
\hline L-Histidine & - & - & - & - & + & + & - & - & - \\
\hline L-Ornithine & + & - & - & + & + & + & - & - & - \\
\hline
\end{tabular}

${ }^{a}$ Data for $\mathrm{H}_{2} \mathrm{~S}$ production, gelatin hydrolysis, and aerobic acid production from carbohydrates for all species except $A$. atlanticum and $A$. meteori are derived from Ahrens (1). Symbols:,$+>80 \%$ of strains positive; $(+),>80 \%$ of strains weakly positive; $\mathrm{D}, 21$ to $79 \%$ of strains positive;,$->80 \%$ of strains negative.

phenotypic characteristics. However, their LMW-RNA profiles were so different from those of the other five species (Fig. 2 and 3) that they cannot be included in the genus Agrobacterium. According to their overall characteristics, presented in Tables 2 and 4, these species may be regarded as separate taxa in the family Rhizobiaceae as described by Jordan (22).

\section{ACKNOWLEDGMENTS}

We are indebted to Christa Summa and R. Handels for their skillful technical assistance and to F. Riemann and Friedel Hinz for preparing the photomicrographs of marine Agrobacterium strains.

Part of this study was supported by funds from the German Ministry of Research and Technology to one of us (M.G.H.).

\section{REFERENCES}

1. Ahrens, R. 1968. Taxonomische Untersuchungen an sternbildenden Agrobacterium-Arten aus der westlichen Ostsee. Kieler Meeresforsch. 24:147-173.
2. Ahrens, R., and G. Rheinheimer. 1967. Über einige sternbildende Bakterien aus der Ostsee. Kieler Meeresforsch. 23:127136.

3. Allen, O. N., and A. J. Holding. 1974. Genus II. Agrobacterium Conn 1942, 359. Nom. gen. cons. Opin. 33, Jud. Comm. 1970, 10, p. 264-267. In R. E. Buchanan and N. E. Gibbons (ed.), Bergey's manual of determinative bacteriology, 8 th ed. The Williams \& Wilkins Co., Baltimore.

4. Baumann, L., R. D. Bowditch, and P. Baumann. 1983. Description of Deleya gen. nov. created to accommodate the marine species Alcaligenes aestus, $A$. pacificus, $A$. cupidus, $A$. venustus, and Pseudomonas marina. Int. J. Syst. Bacteriol. 33:793802.

5. De Ley, J. 1968. Molecular biology and bacterial phylogeny. Evol. Biol. 2:103-156.

6. De Ley, J. 1970. Reexamination of the association between melting point, buoyant density, and chemical base composition of deoxyribonucleic acid. J. Bacteriol. 101:738-754.

7. De Ley, J. 1978. Modern molecular methods in bacterial taxonomy: evaluation, application, prospects, p. 347-357. In Proceedings of the 4th International Conference on Plant Pathology and Bacteriology. Angers 1978. 
8. De Ley, J., H. Cattoir, and A. Reynaerts. 1970. The quantitative measurement of DNA hybridization from renaturation rates. Eur. J. Biochem. 12:133-142.

9. De Smedt, J., and J. De Ley. 1977. Intra- and intergeneric similarities of Agrobacterium ribosomal ribonucleic acid cistrons. Int. J. Syst. Bacteriol. 27:222-240.

10. Gillis, M., J. De Ley, and M. De Cleene. 1970. The determination of molecular weight of bacterial genome DNA from renaturation rates. Eur. J. Biochem. 12:143-153.

11. Grierson, D. 1982. Gel electrophoresis of RNA, p. 1-38. In D. Rickwood and B. D. Hames (ed.), Gel electrophoresis of nucleic acids. IRL Press Ltd., Oxford.

12. Grimont, P. A. D. 1988 . Use of DNA reassociation in bacterial classification. Can. J. Microbiol. 34:541-546.

13. Hamana, K., and S. Matsuzaki. 1990. Polyamines and their biosynthetic activities in nonphytopathogenic marine agrobacteria. Can. J. Microbiol. 36:567-572.

14. Hartford, T., and P. H. A. Sneath. 1988. Distortion of taxonomic structure from DNA relationships due to different choice of reference strains. Syst. Appl. Microbiol. 10:241-250.

15. Hartford, T., and P. H. A. Sneath. 1990. Experimental error in DNA-DNA pairing: a survey of the literature. J. Appl. Bacteriol. 68:527-542.

16. Höfle, M. G. 1988. Identification of bacteria by low molecula weight RNA profiles: a new chemotaxonomic approach. J. Microbiol. Methods 8:235-248.

17. Höfle, M. G. 1990. Transfer RNAs as genotypic fingerprints of eubacteria. Arch. Microbiol. 153:299-304.

18. Höfle, M. G. 1990 . RNA chemotaxonomy of bacterial isolates and natural microbial communities, p. 129-158. In J. Overbeck and R. Chrost (ed.), Aquatic microbial ecology-biochemical and molecular approaches. Springer-Verlag, New York.

19. Huss, V. A. R., H. Festl, and K. H. Schleifer. 1983. Studies on the spectrophotometric determination of DNA hybridization from renaturation rates. Syst. Appl. Microbiol. 4:184-192.

20. Jenni, B., M. Aragno, and J. K. W. Wiegel. 1987. Numerical analysis and DNA-DNA hybridization studies on Xanthobacter and emendation of Xanthobacter flavus. Syst. Appl. Microbiol. 9:247-253.

21. Jennings, A. V. 1898-1900. On a new genus of bacteria (Astrobacter). Proc. R. Irish Acad. Dublin Ser. 3 5:312-316 and plates VI and VII.

22. Jordan, D. C. 1984. Family III. Rhizobiaceae Conn 1938, 321, p 234-235. In N. R. Krieg and J. G. Holt (ed.), Bergey's manual of systematic bacteriology, vol. 1. The Williams \& Wilkins Co., Baltimore.

23. Kersters, K., and J. De Ley. 1984. Genus III. Agrobacterium Conn 1942, 359, p. 244-254. In N. R. Krieg and J. G. Holt (ed.) Bergey's manual of systematic bacteriology, vol. 1. The Williams \& Wilkins Co., Baltimore.

24. Kersters, K., and J. De Ley. 1984. Genus Alcaligenes Castellani and Chalmers 1919, 936, p. 361-373. In N. R. Krieg and J. G. Holt (ed.), Bergey's manual of systematic bacteriology, vol. 1. The Williams \& Wilkins Co., Baltimore.

25. Knösel, D. 1984. Genus IV. Phyllobacterium (ex Knösel 1962) nom. rev. (Phyllobacterium Knösel 1962, 96), p. 254-256. In N. R. Krieg and J. G. Holt (ed.), Bergey's manual of systematic bacteriology, vol. 1. The Williams \& Wilkins Co., Baltimore.

26. Kolodny, G. M. 1984. An improved method for increasing the resolution and sensitivity of silver staining of nucleic acid bands in polyacrylamide gels. Anal. Biochem. 138:66-67.

27. Koops, H.-P., and H. Harms. 1985. Deoxyribonucleic acid homologies among 96 strains of ammonia-oxidizing bacteria. Arch. Microbiol. 141:214-218.

28. Marmur, J. 1961. A procedure for the isolation of depxyribonucleic acid from micro-organisms. J. Mol. Biol. 3:208-218.

29. Marmur, J., and P. Doty. 1962. Determination of the base composition of deoxyribonucleic acid from its thermal denaturation temperature. J. Mol. Biol. 5:109-118.

30. Palleroni, N. J. 1984. Genus Pseudomonas Migula 1894, 237, p. 141-199. In N. R. Krieg and J. G. Holt (ed.), Bergey's manual of systematic bacteriology, vol. 1. The Williams \& Wilkins Co., Baltimore.

31. Rüger, H.-J. 1985. Benthic studies of the northwest African upwelling region: structures and catabolic potentials of mesophilic bacterial communities. Veröff. Inst. Meeresforsch. Bremerhaven 21:97-114.

32. Rüger, H.-J. 1988. Substrate-dependent cold adaptations in some deep-sea sediment bacteria. Syst. Appl. Microbiol. 11:9093.

33. Rüger, H.-J., and G. Richter. 1979. Bacillus globisporus subsp. marinus subsp. nov. Int. J. Syst. Bacteriol. 29:196-203.

34. Rüger, H.-J., and T. L. Tan. 1983. Separation of Alcaligenes denitrificans sp. nov., nom. rev. from Alcaligenes faecalis on the basis of DNA base composition, DNA homology, and nitrate reduction. Int. J. Syst. Bacteriol. 33:85-89.

35. Rüger, H.-J., T. L. Tan, G. Hentzschel, and M. Naguib. 1983. New denitrifying Agrobacterium and Alcaligenes strains from Weser estuary sediments: taxonomy and physiology. Veröff. Inst. Meeresforsch. Bremerhaven 19:229-243.

36. Schleifer, K. H., and E. Stackebrandt. 1983. Molecular systematics of prokaryotes. Annu. Rev. Microbiol. 37:143-187.

37. Siebert, G., and W. Schwartz. 1956. Untersuchungen über das Vorkommen von Mikroorganismen in entstehenden Sedimenten. Arch. Hydrobiol. 52:321-366.

38. Skerman, V. B. D., V. McGowan, and P. H. A. Sneath (ed.). 1980. Approved lists of bacterial names. Int. J. Syst. Bacteriol. 30:225-420.

39. Slade, P. J., and D. L. Collins-Thompson. 1991. Differentiation of the genus Listeria from other gram-positive species based on low molecular weight (LMW) RNA profiles. J. Appl. Bacteriol. 70:355-360.

40. Stackebrandt, E., R. G. E. Murray, and H. G. Trüper. 1988. Proteobacteria classis nov., a name for the phylogenetic taxon that includes the "purple bacteria and their relatives." Int. J. Syst. Bacteriol. 38:321-325.

41. Stapp, C., and D. Knösel. 1954. Zur Genetik sternbildender Bakterien. Zentralbl. Bakteriol. Parasitenkd. Infektionskr. Hyg. Abt. 2 108:243-259.

42. Weyland, H., H.-J. Rüger, and H. Schwarz. 1970. Zur Isolierung und Identifizierung mariner Bakterien: ein Beitrag zur Standardisierung und Entwicklung adäquater Methoden. Veröff. Inst. Meeresforsch. Bremerhaven 12:269-296. 